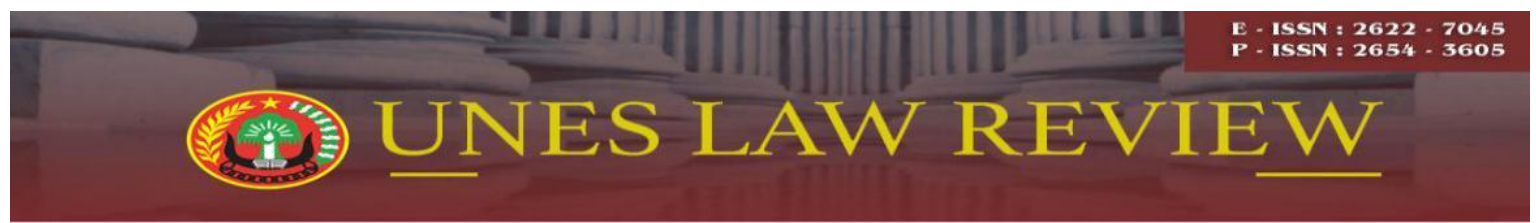

Email: uneslawreview@gmail.com

Online: http://review-unes.com/index.php/law

Volume 2, Issue 3, Maret 2020

\title{
JAMINAN FIDUSIA YANG DIJADIKAN JAMINAN KEMBALI DENGAN TIDAK MELAKUKAN PENGHAPUSAN FIDUSIA MENURUT PRESPEKTIF HUKUM DI INDONESIA
}

\author{
${ }^{1}$ Rinal Efries Situmeang, ${ }^{2}$ Irene Svinarky, ${ }^{3}$ Lisa Simamora \\ ${ }^{1}$ Mahasiswa Program Studi Ilmu Hukum, Universitas Putera Batam \\ Email: pb160710021@upbatam.ac.id \\ 2 Dosen Program Studi ilmu Hukum, Universitas Putera Batam \\ Email: irene@puterabatam.ac.id \\ ${ }^{3}$ Mahasiswa Program Studi Ilmu Hukum, Universitas Putera Batam \\ Email: pb160710050@upbatam.ac.id
}

\begin{abstract}
Fiduciary is shift that did by fiduciary owner to fiduciary receiver, while for up object ability that present on object owner. Number law 42 Years 1999 about Fiduciary Surety or more recognized with UUJF is attributed to make and gives protection of the parties so fiduciary transactions to the fore also expected to qualify law on fiduciary. Fiduciary will erase if object that made by indemnity being paid off by its loan, while is fiduciary was placed to an object really being prohibited for fiduciary giver for vouch in as indemnity is back but a long cry intention of Section 17 UUJF with Section 23 sentences (2) UU JF. In Section 23 sentences (2) bear out one of rule it that object that becomes fiduciary indemnity can be shifted if get agreement in writing of fiduciary receiver but variably its thing with what does he meant on Section 25 sentences (1) UUJH. Section 25 sentences (1) UUJH where terminological its formulation that fiduciary indemnity delete because of that fiduciary indemnity is alone was demolish; then indemnity that is used for fiduciary was end its book debt; then fiduciary giver to fiduciary receiver; rights release on fiduciary indemnity by fiduciary receiver; and if goods that becomes fiduciary indemnity disappear therefore fiduciary will erase. Observational type that is used in this research is jurisdictional observational type normative. Fiduciary indemnity terminological UUJF bases Section 17 be borne out that: Information hits indemnity object as object that stills in fiduciary indemnity and still enrolled therefore fiduciary giver is prohibited to do fiduciary and Section 17 not if fiduciary receiver accept therefore get to make that indemnity as back indemnity without ask for fiduciary indemnity deletions as royal. To the effect to list that fiduciary back as surety of giving afters fiduciary fiduciary pays off that goods is subject to be not remove prefentif's rights divides fiduciary receiver.
\end{abstract}

Kata Kunci: Fidusia Repeat; Roya Fidusia; Prespektif Hukum. 


\section{PENDAHULUAN}

Pertumbuhan ekonomi dapat dilihat dari berkembang sejalan dengan adanya persaingan usaha dimana lembaga pembiayaan yang merupakan alternatif yang dapat dicari oleh konsumen agar kebutuhannya terpenuhi. Kekhawatiran yang mungkin dialami oleh masyarakat berpenghasilan rendah tidak perlu lagi muncul, dikarennakan telah adanya lembaga pembiayaan yang memberikan solusi terhadap permasalahan tersebut. Lembaga pembiayaan bertujuan untuk memberikan bantuan kepada masyarakat dalam mempermudah untuk membeli barang yang menjadi barang kosumsi masyarakat. Perjanjian dapat dilakukan antara pihak perusahaan yang menyediakan pembiayaan atau sering disebut dengan (kreditur) dengan konsumen (debitur) atau nasabah ataupun klien yang menjadi sebutan dalam membuat perjanjian pokok atau perjanjian kredit (Sri Soedewi Masjchoen Sofwan, 1980: 1). Pemberian bantuan berupa kredit yang diberikan kepada masayarakat untuk mempermudah masyarakat, maka masyarakatpun juga harus mengenal beberapa jenis kredit yang menggunakan pembiayaan.

Adapaun jenis-jenis pembiayaan yang sering dipergunakan perusahaan dalam menjalankan bisnisnya seperti: a. Pembiayaan dengan modal pinjaman (kredit perbankan); b. Pembiayaan dengan modal penyertaan (penjualan saham dan modal ventura); c. Pembiayaan dengan pengalihan piutang (factoring), pembiayaan dengan sewa menyewa guna usaha (leasing) dan pembiayaan dengan penerbitan surat berharga (commercial paper, promes dan obligasi) (Naja, 2009). Di dalam melakukan perjanjian baik dengan menggunakan perjanjian kredi ataupun pembiayaan, masyarakat memang perlu diberikan keterangan mengenai fitur apa atau layanan seperti apa yang dikeluarkan oleh pihak bank ataupun pembiayaan. Masyarakat yang masih binggung mengenai aturan, seharusnya sebelum melakukan yang namanya transaksi terlebih dahulu harus mempertanyakan mengenai transaksi yang dilakukan. Banyak sekali transaksi yang dilakukan oleh masyarakat kepada bank ataupun pembiayaan namun masyarakat tekadan cuek dalam menanggapi mengenai aturan dari transaksi tersebut. sehingga ketika sudah terkena masalah, barulah masyarakat menyadari terhadap apa yang dilakukan. Namun setelah terjadi permasalahan baru disadari hal tersebut pasti sudah terlambat.

Oleh sebab itu sebelum melakukan transaksi dalam menjaminkan barang untuk diikatkan pada jaminan fidusia maka terlebih dahulu masyarakat juga harus mengenatui aturannya. Persyaratan yang harus dipenuhi oleh nasabah sangat penting terlebih dahulu dilakukan sebelum nasabah diberikan pinjaman dari jasa keuangan Syarat yang harus dipenuhi oleh nasabah salah satunya yaitu debitur harus menyerahkan suatu jaminan baik yang bergerak maupun tidak bergerak. Perjanjian yang akan dibuatkan oleh Notaris 
terhadap bank yang telah bekerjasama dengan Notaris tersebut, mengikat bank dengan nasabah terhadap jaminan benda bergerak disebut perjanjian jaminan fidusia.

Meskipun jaminan fidusia dapat dilakukan pengalihan hak kepemilikan, yang mana meski telah dialiihkan berdasarkan dasar kepercayaan, namun benda tersebut tatap di dalam pengawasan pemilik dari benda tersebut. Dimana mengenai pengalihan hak kepemilikan melalui jaminan fidusia tersebut dapat dilihat pada Pasal 1 angka (1) UndangUndang Nomor 42 Tahun 1999 tentang Jaminan Fidusia yang disingkat dengan UUJF.

Sesuai dengan Surat Edaran yang dikeluarkan pemerintah yaitu Direktur Jenderal Administrasi Hukum Umum Kementerian Hukum dan Hak Asasi Manusia Republik Indonesia yang disingkat dengan (Ditjen AHU) Nomor AHU-06.OT. 03.01, tertanggal 5 Maret 2013, tentang Secara Elektronik (online) dapat diberlakukan Sistem Pendaftaran Jaminan Fidusia. Aturan tersebut di atur di dalam Peraturan Menteri Hukum dan Hak Asasi Manusia Nomor 9 Tahun 2013 tentang Pemberlakuan Sistem Administrasi Pendaftaran Jaminan Fidusia secara Elektronik. Di dalam Peraturan Menteri Hukum dan Hak Asasi Manusia Republik Indonesia Nomor 10 Tahun 2013 tentang Tata Cara Pendaftaran Jaminan Fidusia secara Elektronik juga mengatur tata cara pendaftaran fidusia secara elektronik. Hal yang dapat menghapuskan jaminan fidusia adalah pelunasan atau pengalihan hak setelah dilakukannya pembayaran. Pengembalian kepada pemberi jaminan fidusia terhadap objek jaminan fidusia yang sebelumnya diikatkan menjadi jaminan kepada penerima jaminan fidusia hal tersebut harus dilakukan. Teori hukum positif juga digunakan di dalam tulisan ini yaitu menelaah dari pengertian di dalam hukum, metodologi hukum yang menyangkut metodologi pembentukan hukum, dan metodologi penerapan. Istilah positif dalam hukum positif memiliki kandungan makna mengenai hukum yang ditetapkan ( gesteld recht). Oleh sebab itu, aturan fidusia yang telah berlaku yang telah ditetapkan di dalam UUJF harus di taati oleh pemberi fidusia dan juga penerima fidusia (Ibrahim, 2005: 85). Suatu permaslaahn akan terjadi dikemudian hari biasanya dengan adanya kelalaian yang dilakukan oleh pihak yang tidak memahami aturan sebelum melakukan transaksi yang akan mereka lakukan. Jadi memang perlu sekali masyarakat diberikan edukasi mengenai aturan hukum agar mereka juga dapat memahami mengenai aturan hukum tersebut. Biasanya sosialisasi dilakukan setelah aturan keluar, namun sebaiknya sosialisasi tidak hanya dilakukan dengan pejabat atau pemerintah saja mengenai aturan tersebut. Sosialisasi yang telah diberikan kepada pejabat atau pemerintah tadi juga harus menyampaikan kepada masyarakat, ketika masyarakat tersebut melakukan transasksi dan diikatkan dalam suatu perjanjian. 
Sesuai apa yang telah dijelaskan oleh penulis di atas maka dapat menggangkat permasalahan sebagai berikut: Bagaimanakah jaminan fidusia menurut UUJF apabila dijaminkan kembali sebelum dilakukannya penghapusan fidusia?

\section{METODE PENELITIAN}

Metode yang digunakan dalam penelitian ini adalah penelitian hukum normatif yaitu dengan menggunakan penelitian hukum kepustakaan mencakup mengenai sistematik hukum, taraf sinkronisasi vertikal dan horisontal, asas-asas hukum, perbandingan hukum serta sejarah hukum. (Soerjono Soekanto dan Sri Mamudji, 2001: 61) Pendekatan yang digunakan di dalam tulisan ini adalah pendekatan perundang-undangan.

Sifat penelitian yang digunakan di dalam penelitian ini adalah deskriptif. Sifat Penelitian deskriptif memiliki tujuan untuk menggambarkan secara tepat sifat-sifat suatu individu, keadaan, gejala atau kelompok tertentu atau untuk menentukan penyebaran suatu gejala, atau untuk menentukan ada tidaknya hubungan antara suatu gejala dengan gejala lainnya dalam masyarkat.

Teknik pengumpulan data yang digunkan dalam melengkapi penelitian ini yaitu studi dokumen, data sekunder dan studi kepustakaan.

\section{HASIL PENELITIAN DAN PEMBAHASAN}

\section{Jaminan Fidusia menurut UUJF Apabila Dijaminkan Kembali maka Dilakukannya Penghapusan Fidusia}

Pendaftaran Sertifikat jaminan fidusia harus didasari dengan pembuatan akta jaminan fidusia yang dibuat oleh Notaris sebagai yang memiliki wewenang sebagai pejabat umum yang melakukan pembuatan akta fidusia, kemudian ditandatangani oleh pihak pemberi fidusia (debitur) dengan penerima fidusia (kreditur). Akta yang telah dibuat, kemudian didaftarkan melalui website: ahu.ac.id dan kemudian setelah didaftarkan maka bukti pendaftaran tadi dapat digunakan sebagai salah satu syarat memintakan sertifikat fidusia. Dibuatnya akta tersebut di depan notaris, sehingga notaris memiliki kewenang atas akta tersebut dan agar lebih berhati-hati di dalam membuatnya. Mengingat masih banyaknya terjadi suatu pelanggaran seperti objek yang belum dilakukannya pencoretan fidusia yang sering diberikan sebutan belum di fidusianya belum di roya tetapi kembali tetap dilakukan penjaminan barang yang sama. Bahasa roya lebih tepat diletakkan pada jaminan Hak Tanggungan, namun sering sekali dalam bahasa sehari-hari fidusiapun ketika bank mau melakukan penghapusan fidusia sering juga istilah roya disebut dalam penghapusan fidusia.

Pendaftaran atau pencatatan adalah hal yang wajib dipenuhi untuk lahirnya jaminan fidusia. Pendaftaran tidak dapat dipisahkan dari perjanjian jaminan fidusia yang memiliki 
defenisi yuridis. Pendaftaran suatu benda untuk diikatkan jaminan fidusia dapat diwujudkan dari asas publisitas dan kepastian hukum, arti yang demikian menegaskan bahwa objek yang telah diikat dengan perjanjian jaminan fidusia apabila tidak melakukan pendaftaran merupakan perbuatan hukum yang sia-sia.

Pencatatan jaminan fidusia harus didasari dengan adanya suatu perjanjian fidusia. Pendaftaran tersebut telah dituangkan dalam UUJF yang mencari kepastian hukum. Pendaftaran memberikan hak yang didahulukan (preferen) kepada penerima fidusia terhadap kreditor yang lain.(Salim HS:2011:82) Keluarkannya Peraturan Tata Cara Pendaftaran Jaminan Fidusia Secara Elektronik, maka cara online merupakan cara yang dilakukan dalam mendaftarkan fidusia. Pada dasarnya untuk melakukan pendaftaran fidusia tidak ada yang berubah dari sistem sebelumnya, hanya saja pada saat ini tidak perlu datang ke kantor pendaftaran fidusia untuk melakukannya, sesuai perkembangan teknologi sekarang ini pemohon bisa langsung saja mengakses website www.fidusia.ahu.go.id. Untuk mendafatarkan jaminan fidusia tersebut

Di fidusia online perlu diperhatikan adalah untuk segera dilakukan perubahan dalam sertifikat jaminan fidusia dan, masalah roya fidusia agar mencegah kerugian dari debitur untuk terjadinya fidusia ulang. Terjadinya penghapusan fidusia karena pemberi jaminan fidusia telah melunasi kewajibannya sepenuhnya. Ada beberapa hal yang mengatur tentang hapusnya jaminan fidusia, seperti halnya telah dituliskan didalam isi undang-undang tentang jaminan fidusia sebagai berikut :

1. Hapusnya karena hutang telah lunas.

2. Penghapusan karena Pelepasan dan pengaliahan hak

3. Musnahnya atau hilangnya barang jaminan.

Dengan hapusnya objek jaminan fidusia, maka penerima fidusia harus langsung membuatkan surat pelunasan dan memberitahukan penghapusan fidusia secara online paling lambat 7 hari setelah lunasnya hutang pemberi fidusia atas jaminan fidusia yang bersangkutan dengan dilampiri bukti pelunasan dari penerima fidusia. Melakukan fidusia ulang tanpa dilakukan roya fidusia, hal ini tidak diperbolehkan untuk dilakukan karena objek yang sudah didaftarkan sertifikat fidusia. Hak kepemilikan terhadap barang yang diikatkan jaminan fidusia, untuk sementara waktu sambil utang dari pemberi fidusia dilunasi maka penerima fidusia belum penuh menguasai objek fidusia tersebut. Pemberi fidusia dapat melakukan fidusia kembali terhadap objek jaminan fidusia tersebut, apabila jaminan fidusia tersebu telah mendapat bukti, bahwa telah dilakukan pencoret dari daftar buku fidusia online. Dengan melakukan penghapusan fidusia menunjukkan bahwa objek tersebut telah hapus dari pencatatan jaminan fidusia di kantor pendaftaran fidusia dan 
dapat dijadikan sebagai objek jaminan fidusia kembali. Jika objek jaminan tersebut masih tetap didaftarkan tetapi belum melakukan roya maka dapat dipastikan bahwa hal seperti itu telah terjadi fidusia ulang.

Tujuan lahirnya Undang-Undang tentang Jaminan Fidusia Nomor 42 Tahun 1999 adalah untuk menjamin akan lahirnya suatu kepastian hukum terhadap objek fidusia. Menurut J. Satrio, mengungkapkan pengaturan jaminan fidusia akan lebih pasti melalui undang-undang tentang hak dan kewajiban yang akan timbul dari suatu perjanjian jaminan fidusia, dengan demikian akan menambah suatu kepastian hukum mengenai hal tersebut. Menelaah norma hukum ialah mengkaji substansi hukumnya.

Lawrence M. Friedman menyatakan bahwa substansi hukum ialah berhubungan dengan produk hukum. Apakah penyusunan peratuaran perundang-undangan telah sesuai dengan materi dari isu-isu hukum yang ada dimasyarakat?. Pelanggaran yang akan diberi jika norma hukumnya tegas. Akibat dari perbuatan yang menimbulkan pelanggaran hukum akan diberi sanksi. Sanksi yang dijatuhkan bagi pelanggaran hukum apabila dilihat dari sifatnya bertujuan untuk mendidik kepada seseorang atau untuk mengobati. (Modakir Iskandar Syah, 2008:18) Untuk menjamin kepastian dalam pelaksanaannya maka Produk hukum berupa aturan-aturan harus memiliki ketegasan . Kepastian hukum akan didapatkan apabila aturan tersebut memang tegas dijalankan, namun apabila peraturan tersebut tidak tegas dijalankan maka aturan hukum tersebut hanya sebatas aturan saja.

UUJF di dalam Pasal 25 ayat (3) ini, ketegasan dalam pelaksanaan belum terlaksana dimana pasal tersebut bersifat anjuran dan bagi penerima tidak merupakan kewajiban melakukan roya fidusia. Anjuran tersebut dilakukan agar telah hapusnya Jaminan Fidusia dapat diberitahukan kepada Kantor Kemenkumham yang menerbitkan Sertifikat Fidusia tersebut . Sanksi juga tidak diatur di dalam UUJF ini mengenai masyarakat telah terikat dengan fidusia, kemudian tidak melakukan roya fidusia untuk pelunasan utang. Tentunya pasal ini masih jauh dari kata tegas karena pasal ini menjadikan kreditur kehilangan privilege nya apabila tidak diikatkan jaminan fidusia. Selain itu di dalam Peraturan Menteri Hukum dan Hak Asasi Manusia Republik Indonesia Nomor 10 Tahun 2013 tentang Tata Cara Pendaftaran Jaminan Fidusia secara elektronik aturan ini ada merupakan penyelarasan dengan UUJF yang telah ada yang terkait dalam penghapusan roya fidusia ini. Dalam aturan ini lebih ditekankan pada anjuran untuk melakukan roya fidusia. Sangat disayangkan dalam aturan ini tidak tegas dalam menerapkan sanksi apabila jaminan fidusia yang masih dipasangkan pada suatu benda juga harus dihapus roya fidusianya sebelum dipasangkan ulang kembali jaminan fidusia yang baru.

Terhadap tata cara pendaftaran fidusia juga ada aturan yang mengatur mengenai hal tersebut yaitu Peraturan Pemerintah Nomor 21 Tahun 2015 tentang Tata Cara Pendaftaran 
Jaminan Fidusia dan Biaya Pembuatan Akta Jaminan Fidusia, dimana dapat lihat di aturan ini adanya kewajiban bagi Penerima Fidusia, kuasa, atau wakilnya memberitahukan hapusnya Jaminan Fidusia secara tertulis. Selain itu, mengenai masa tenggang juga sudah ditentukan paling lambat 14 hari setelah hapusnya Jaminan

Fidusia yang bersangkutan. Namun di dalam mengenai tata cara pendaftaran jaminan fidusia ini tidak tertulis sanksi tegas bagi kreditur yang menawarkan pengikatan kembali jaminan fidusia yang belum dihapuskan royanya namun diikatkan kembali sebagai objek jaminan utang.

Oleh sebab itu maka penerima fidusia jadi tidak mementingkan untuk roya fidusia. Kemudian, mengenai Peraturan Menteri Keuangan Nomor: 130/PMK.010/Tahun 2012 tentang Pendaftaran Jaminan Fidusia Bagi Perusahaan Pembiayaan yang melakukan Pembiayaan Konsumen untuk Kendaraan Bermotor dengan Pembebanan Jaminan Fidusia, di dalam aturan inipun tidak ada menegaskan mengenai aturan penghapusan roya dan juga sanksi. Hal ini karena Kementerian yang mengeluarkan aturan tersebut juga berbeda. Dalam hal ini pihak bank tidak memiliki privilege, karena tidak diikuti dengan pengikatan jaminan fidusia.

Oleh karena itu akan mengakibatkan tidak ada kepastian hukum atas roya fidusia ditujukan agar adanya kapastian hukum yang diberikan kepada debitur, dan krediturpun sebagai kreditur preferen tetap memiliki haknya. Suatu wujud dari ketegasan aturan merupakan adanya sanksi. Sanksi yang telah dinyatakan dalam hukum sangatlah berguna untuk dilahirkannya suatu kepastian hukum. Dalam undang-undang yang tidak mengatur secara tegas tentang roya fidusia mengakibatkan pihak yang berkewajiban untuk mematuhi peraturan tersebut, sering kali tidak merasa telah melanggar kewajibannya untuk mematuhi peraturan tersebut. Suatu peraturan yang dibuat dengan tegas memberikan suatu kepastian hukum kepada pelaksanaan pemerintah. Produk hukum (product of law) yang mengatur roya fidusia (roya fiduciary) terlalu lemah. Akibat dari lemahnya suatu produk hukum yang mengatur tentang roya fidusia tidak mampu mewujudkan kebutuhan masyarakat. Ketidaktegasan produk hukum tentang roya fidusia akan sangat sulit menciptakan suatu kepastian hukum. Mengakibatkan tidak sedikit para lembaga pembiayaan akan tetap melakukan fidusia ulang.

Suatu lembaga jaminan yang mengikatkan objek jaminan terhadap barang yang akan menjadi jaminan utang seperti hak tanggungan, hipotek maupun jaminan fidusia harus melakukan penghapusan atau pembebasan pembebanannya. Keharusan ini, diikatkan 
sepanjang pembebanan atas objek jaminan kredit dilakukan melalui kewajiban pendaftaran, maka penghapusan pembebanan hutang atas objek jaminan tersebut dilakukan pada instansi yang melakukan pendaftaran pembebanan. Apabila di dalam sistem hak tanggungan debitur telah melunasi seluruh hutang atau kewajiban kepada kreditur atas tanah yang menjadi jaminan maka setelah itu dilakukanlah proses roya atas hak tanggungan tersebut tujuannya adalah memberikan jaminan kepada masyarakat agar keadaan tanah yang telah dibebankan tersebut sudah bersih dari pembebanan utang. Untuk jaminan fidusiapun juga sama dengan apa yang telah dinyatakan di atas, sepanjang roya belum dilakukan penghapusan terhadap objek jaminan fidusia maka tidak dapat dinyatakan bebas dari pengikatan yang telah dilakukan di dalam sertifikat fidusia tersebut. Roya fidusia merupakan suatu kewajiban yang harus dilaksanakan oleh pemberi fidusia apabila kewajiban pemberi fidusia telah terpenuhi dan apabila objek jaminan fidusia yang belum melakukan roya, tidak dapat dijadikan objek jaminan fidusia kembali. Terkait dengan objek jaminan fidusia yang akan difidusiakan kembali dalam keadaan belum melakukan roya fidusia, hal tersebut dilarang secara spesifik dalam Peraturan Pemerintah Nomor 21 Tahun 2015.

Selama jaminan fidusia tidak diberitahukan oleh penerima fidusia kepada kantor pendaftaran fidusia dan kantor pendaftaran fidusia yaitu Kementerian Hukum dan Hak Asasi Manusia Direktur Administrasi Hukum Umum belum menerima dan mengeluarkan bahwa sertifikat jaminan fidusia tidak berlaku, maka objek jaminan fidusia tersebut masih akan tetap terdaftar menjadi jaminan hutang. Maka sesungguhnya tujuan dari roya fidusia ialah untuk membebaskan benda yang menjadi objek jaminan fidusia, bebas dari jaminan fidusia. Untuk objek jaminan fidusia yang belum melakukan penghapusan sertifikat jaminan fidusia, tidak dapat dijadikan sebagai jaminan untuk melakukan fidusia kembali.

Akibat hukum yang akan timbul apabila pemberi fidusia melakukan fidusia ulang, yaitu :

1. Apabila ada kreditur kedua yang diberikan objek jaminan fidusia sebagai jaminan utang, namun kreditur kedua tidak mengetahui bahwa objek yang dijaminkan kepadanya telah diikatkan jaminan fidusia maka kreditur tersebut akan kehilangan privilege. Pemberian privilege secara otomatis melekat kepada orang pertama yang menjadi kreditur terhadap objek utangnya dimana hal ini diatur di dalam Pasal 27 UUJF.

2. Pemberian Sanksi Pidana Kepada Pemberi Fidusia akibat dari perbuatan pemberi fidusia yang melakukan secara sadar fidusia ulang, UUJF memberikan sanksi 
pidana, sebagaimana diatur dalam Pasal 35 kepada debitor yang nakal karena memberikan keterangan yang menyesatkan sehingga terjadi fidusia yang dilarang ini, dengan pidana penjara paling singkat 1 (satu) tahun dan paling lama 5 (lima) tahun dan denda paling sedikit Rp. 10.000.000,-(sepuluh juta rupiah) dan paling banyak 100.000.000,- (seratus juta rupiah).

Sangatlah wajar dan tepat jika pemberi fidusia diberikan sanksi atas perbuatannya melakukan fidusia ulang apabila tanpa sepengetahuan penerima fidusia, namun tidak wajar diterima oleh si pemberi fidusia apabila menerima sanksi jika bukan dari pemberi fidusia yang mau. Tawaran pasti akan dating kepada pemberi fidusia jika pemberi fidusia membayar utang dengan lancar. Masalahnya akan sangat merugikan debitor jika dilakukan fidusia ulang tanpa melakukan penghapusan sertifikat jaminan fidusia karena apabila dilakukan oleh pemberi fidusia (debitur) dan jika kreditnya macet maka pemberi fidusia akan dikenakan sanksi sesuai dengan Pasal 35 UUJF

Namun, jika ditinjau dari Pasal 25 ayat (3) UUJF, menjelaskan bahwa yang berkewajiban untuk melakukan roya fidusia adalah penerima fidusia (kreditur), bukan pemberi fidusia (debitur). Jadi, disini pemberi fidusia juga harus memiliki kehati-hatian dalam sanksi pidana yang akan nantinya mereka dapatkan apabila tidak memintakan roya fidusia ketika utang yang mereka hampir lunas, ditawarkan kembali untuk dibuatkan perjanjian baru tanpa dilakukan penghapusan jaminan fidusia dan diikatkan dengan jaminan fidusia baru. Pihak bank tentunya tidak keberatan apabila masyarakat yang bersedia dalam melakukan peminjaman ulang menguruskan hal tersebut. Namun dengan tulisan ini memiliki tujuan agar masyarakat sadar terhadap hukum, bahwa melakukan roya setelah pelunasan utang harus dilakukan, jangan sampai pemberi fidusia lalai terhadap hal tersebut. Apabila pemberi fidusia ingin mengajukan lagi pinjaman ke bank atau pembiayaan yang sama tidak ada yang akan mempermasalahkan nantinya, asalkan wanprestasi tidak dilakukan oleh pemberi fidusia terhadap utangnya.

Dari penjelasan di atas saharusnya debitur telah berhak atas jaminan tersebut apabila dilakukan pelunasan utang. Namun adanya itikad baik yang dimiliki oleh debitor dalam membayar uang pinjaman, membuat bank merasa tertarik untuk memberikan pinjaman kembali. Ketertarikan itulah yang membuat bank menawarkan pinjaman kembali kepada debitur tanpa diikatnya dengan jaminan fidusia. Pihak bank berdasarkan kepercayaan memberikan pinjaman ulang kepada kepada debitur. Apabila debitur tidak memiliki keinginan kembali untuk meminjam, maka jaminan yang tadi telah dibayar lunas, tidak akan dikembalikan dulu kepada debitur, namun harus dihapuskan mengenai roya fidusia. Pernyataan yang seharusnya tidak tepat adalah apabila pemberi fidusia dituduh melakukan fidusia ulang, dikarenakan objek jaminan fidusia belum diroya fidusia oleh 
penerima fidusia, walaupunh secara unsur menurut Pasal 17 Undang-Undang Jaminan Fidusia sudah terpenuhi. Penerima Fidusia dalam hal ini tidak layak untuk menerima akibat hukum berupa penjatuhan pidana terhadapnya.

Dalam hal ini yang dijatuhkan akibat hukum atas timbulnya perbuatan fidusia ulang harusnya adalah penerima fidusia. Karna sangat relevan penerima fidusia lah yang tidak memberitahu pada kantor pendaftaran fidusia sehingga pemberi fidusia melakukan fidusia ulang. Dalam hal ini Penerima fidusia mengembalikan status objek jaminan tersebut masih dalam keadaan terdaftar, akibatnya akan membuat pemberi fidusia menjaminkan kembali objek tersebut, dan terjadilah fidusia ulang.

\section{PENUTUP}

Undang-undang Jaminan Fidusia masih terasa lemah. sehingga atas lemahnya produk hukum dalam roya fidusia tidak dapat memenuhi kebutuhan masyarakat. Wujud dari ketegasan hukum harus menegaskan sanksi hukum kepada yang melanggar peraturan. Produk hukum yang telah ada akan meningkatkan terjadinya kembali fidusia ulang dikarenakan kepastian hukum atas roya fidusia tidak ada. UUJF memberikan sanksi pidana, sebagaimana diatur dalam Pasal 35 kepada debitor bukan kepada kreditur yang memasangkan objek jaminan belum dihapus royanya. Hal inilah yang menjadikan kreditur dapat meminjamkan kembali tanpa meroya dan melakukan pemasangan jaminan fidusia terhadap objek yang belum diroya merasa hal tersebut tidak menjadi masalah.

\section{DAFTAR PUSTAKA}

\section{Buku Taks:}

Ibrahim, Johnny, 2005. Teori \& Metodologi Penelitian Hukum Normatif, Cetakan Pertama. Malang: PT. Bayumedia Publishing

Naja. HR. Daerng, 2009. Pengantar Hukum Bisnis Indonesia, Cetakan Pertama. Yogyakarta: PT. Buku Kita.

Salim, HS. 2011. Perkembangan Hukum Jaminan di Indonesia. Jakarta:Raja Grafindo Persada.

Soekanto, Soerjono dan Sri Mamudji. 2011. Penelitian Hukum Normatif Suatu Tinjauan Singkat. Jakarta:Raja Grafindo Persada.

Sofwan, Sri Soedewi Masjchoen. 1980. Hukum Jaminan di Indonesia, PokokPokok Hukum Jaminan dan Jaminan Perorangan. Yogyakarta:Liberty Offset.

Syah, Modakir Iskandar. 2008. Pengantar Ilmu Hukum dan Tata Hukum Indonesia, Jakarta:Sagung Seto.

\section{Peraturan Perundang-Undangan:}

Undang-Undang Nomor 42 Tahun 1999 tentang Jaminan Fidusia 
Peraturan Menteri Keuangan Nomor 130/PMK.010/Tahun 2012 tentang Pendaftaran Jaminan Fidusia Bagi Perusahaan Pembiayaan yang Melakukan Pembiayaan Konsumen Untuk Kendaraan Bermotor Dengan Pembebanan Jaminan Fidusia.

Peraturan Menteri Hukum dan Hak Asasi Manusia Republik Indonesia Nomor 10 Tahun 2013 tentang Tata Cara Pendaftaran Jaminan Fidusia Secara Elektronik.

Peraturan Pemerintah Nomor 21 Tahun 2015 tentang Tata Cara Pendaftaran Jaminan Fidusia dan Biaya Pembuatan Akta Jaminan Fidusia. 